\title{
SELECTIONS FROM EMBRYOGENESIS
}

\section{RICHARD GROSSINGER}

Berkeley

We are incarnated in a world where the slaughter of innocents has reached epidenic levels and members of our species treat other species as objects, statistics, or mere industrial machinery. Animals are hunted and tortured for pleasure, butchered for food we do not need, and maimed in useless experiments. Guinea pigs are injected with carcinogens, cats are lobotomized, and monkeys are made to run on treadmills until they drop from exhaustion, but the treadmill never stops. There is no one to intercede for their lives. They are true political prisoners. Behind the masks of self-important scientists and so-called objective experiments sits merely another legally protected pornographer. Of course, the experimenter imagines his/her tests are important in the context of the acaderic bureaucracy he/she serves; he/she loses planetary perspective: the animals are defined as different from us in a way that justifies his/her going as far as he/she wants without doubt or remorse. Does he/she not see that their bare liver and nerve sheaths are his/her liver and nerve sheaths, that they shed the same blood and weep the same tears? At least those "savages" who tortured and maimed their captives did so in a ceremony that recognized the courage and honor of the victim, and then put their own lives on the line in the same battle.

Most experiments are arrogant and useless, they do not even have to occur. We cannot disguise our brutality behind statistics and careerist papers. We are far too old for that; we have been through the executions of the tribal elders and the sacrifice of children, women, and other sentient beings to the dark spirits behind the sun.

The mayhem of our species comes not only from misogyny, not only from the traumas of

COPYright (C RICHARD GROSSINGER 1986

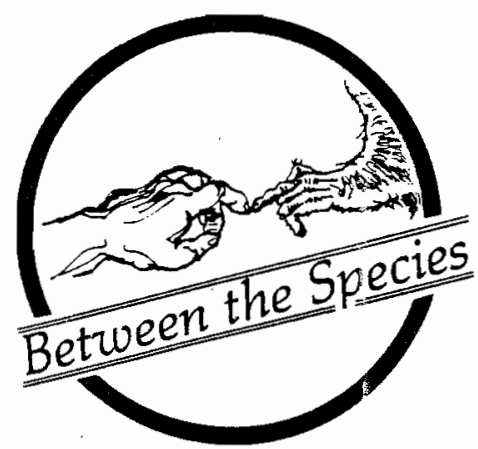

brutalized childhoods; it is also what we inherit from not being human (though not necessarily from being animal). It all happened so long ago: even the old men of the Australian Aborigine tell us it was at the dawn of time, or before time itself. The mythologized account of the crime echoes through the generations: "The men of the Dreaming committed adultery, betrayed and killed each other, were greedy, stole and committed the very wrongs conmitted by those now alive."

In the surmer of 1985, will Baker was invited on a hunting trip in the Peruvian Amazon by two Ashininka Indians, Carlos and Cunado. Soon after they began tracking, a monkey couple ("their faces small and old as time," Baker writes) coines through the trees to look at them. Cunado nocks his arrow, draws, and fires. The female starts as the shaft enters her small body; her fingers fondle its hardness, and she drags herself back and forth, uncomprehending. The unsuspecting male runs up to her and pulls at her shoulder, trying to hurry her away. Cunado's next arrow pierces him, and he bolts from her aid and pinwheels through the branches. The hunters "hoot at this slap-stick agony, this silly tale of fidelity." The question is not, Why do we kill for food? (Not yet anyway.) .The question is, Why are we laughing? How long can we remain in the jungle in darkness in a night of faraway stars?

Even Freud must have realized, in the remorse of his later years, that the primal act goes far beyond the genital symbolism in which it masks itself. It is a transforma-

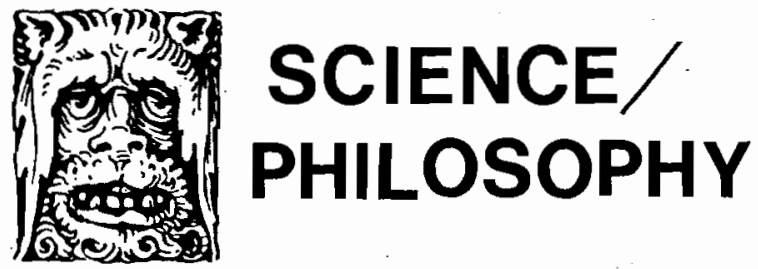


tion rite happening neither here nor elsewhere, neither in time nor outside of time, and involving events indecipherable, as such, but fundamental to the crisis of human life:

"I saw the soul of a man. It came like an eaglehawk. It had wings, but also a penis like a man. With the penis as a hook it pulled my soul out by the hair. My soul hung from the eagle's penis and we flew first toward the east. It was sunrise and the eaglehawk man made a great fire. In this he roasted my soul. My penis became quite hot and he pulled the skin off. Then he took me out of the fire and brought me into the camp. Many sorcerers were there but they were only bones like the spikes of a porcupine.

"Then we went to the west and the eaglehawk man opened me. He took out my lungs and liver and only left my heart. We went further to the west and saw a small child. It was a demon. I saw the child and wanted to

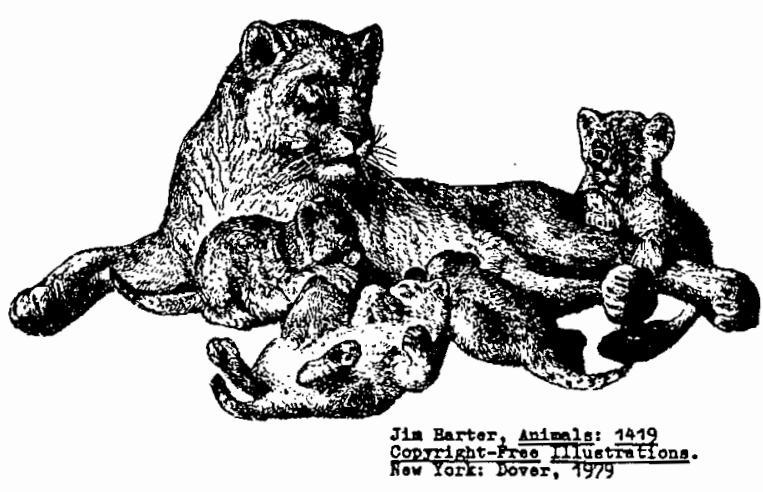

throw the nankara (magical) stones at it. But my testicles hung down and instead of the stones a man came out of the testicles and his soul stood behind my back. He had a very long kalu katiti (skin hanging down from both sides of the subincised penis) with which he killed the demon child. He gave it to me and I ate it."

There is no longer any name for this. There is no tribunal, no judge. There isn't even a convenient psychosis. The death camps appear on the face of history like raindrops splattered on the glass. In the Australian version it isn't malevolent; it is just a shadow masked by a nightmare itself masked by the rudiments of a ceremony. And if we hope to find the evidence or explanation for it in the embryology described elsewhere in these pages, we will be as sorry as those who look to the documents and (now) the videotapes of history in an effort to escape it. We are not likely to find our way out by the animal or the aboriginal shaman either.

In 1761 Georg Wilhelm Steller described an instance of loyalty on the battlefield among sea cows attacked with harpoons by Russian sailors:

"When an animal caught with the hook began to move about somewhat violently, those nearest in the herd began to stir also and feel the urge to bring succour. To this end some of them tried to upset the boat with their backs, while others pressed down the rope and endeavoured to break it, or strove to remove the hook from the wound in the back by blows of their tail, in which they actually succeeded several times. It is most remarkable proof of their conjugal affections that the male, after having tried with all his might, although in vain, to free the female caught by the hook, and in spite of the beating we gave him, nevertheless followed her to the shore, and that several times, even after she was dead, he shot unexpectedly up to her like a speeding arrow. Early the next morning, when we came to cut up the meat and bring it to the dugout, we found the male again standing by the fernale, and. - once more on the third day when I went there by myself for the sole purpose of examining the intestines."

The expedition slaughtered so many of these animals that they were extinct within twenty-seven years of their discovery. To many scientists that is the only crime--but that is too much grief for us, too little for Steller's sta cow. It animals have rights, if they exist (like us) to experience and explore the universe, to feel the ancient wonders of their tissues, then they have rights as individuais, not just as members of endangered species. But there seems little chance of remedy in the next century or even the next millennium, if we ourselves survive. Justice for animals is a cause we are still approaching at great distance.

Instead, we have in the present the acrimonious debate between those who uphold the right of the woman to abortion and those who uphold the right of the foetus to life. The battlelines are, as usual, drawn in the wrong place. To put such weight on the lives of the unborn is sanctimonious unless the plea for life is a general plea of compassion for all sentient beings (or at least all human beings). To make accusations of murder a- 
gainst women who abort unwanted embryos without opposing slaughter and oppression in general is not charity; it is moral duplicity. What about the millions of children and animals who die so that other creatures can maintain a higher standard of living and consume them and their goods;? What about the murders of children and adults in the undeveloped world, either directly through the armies and police of the nuclear-scientific hegemonies and their client states, or indirectly through policies of economic imbalance and resource exploitation? Do the anti-abortionists oppose killing in war? Do they oppose the mass production of implements of torture and murder to be sold to the highest bidder or provided to our surrogate enforcers? Do they think the universe, or, for that matter, God Himself, feels any less pain for the slaughter of the wolf or giraffe than for the abortion of the foetus? Are not the fist and the frog foetal souls in other states, equally impregnated with nerves? Those who bomb abortion clinics as avenging angels should also be freeing animal souls from death camp laboratories and attacking weapons factories.

This nations exists through the theft of land from its previous occupants, the systematic murder of aborigines, embryos and all. But, unfortunately, conquest has been the rule rather than the exception. Some tribes kill their own young to keep families small; surely they would destroy other tribes for a spring, a valley, or hunting ground. Infanticide and genocide form a cycle over millennial time.

But to say that the embryo is not alive, or not human--not yet sentient and thus not murderable--is another form of self-deceit. It is impossible to abort the foetus without killing the person incarnating there. But we mistake rhetoric and journalism for reality. The marketplace and work force replace our inner voices, our somatic wisdom, replace even desire. Goods seem to interest us more than ourselves, consumption more than the lucid calm of the body at rest. "Pro-choice" means nothing if it does not include the unarticulated choice of the living soul of the embryo. Its hunger for life, its desire for unfoldment, is as strong as ours, even before it has words in which to express a personality. A court may rule that an embryo has no rights, but the cells and gathering consciousness of the creature are real and seek manifestation. We should not dimin- ish the mystery we are by pretending that all experiences can be institutionalized or sold. Courts of law cannot redress the seeming biological injustice making women alone the carriers of zygote. Progressive technology with its massive bureaucratic governments does not understand who we are, so we should not put our identity in its hands. The role of the woman as the bearer of life is ancient beyond words; it is not just an unfair allotment or a capitalist exploitation; it is an unsolved mystery and an opportunity, as is life itself.

Even the death of a fly requires atonement, although we may push it out of mind a thousands times, as we crush the body, before we notice. The makers of weapons operate under the same anaesthetic until they are awake.

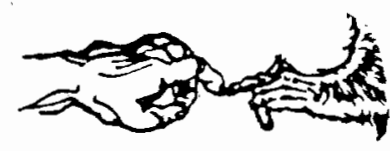

Humans come into being as animals; yet there is a gulf in the animal world between "us" and "them." On our side creatures have conscious awareness of their existence in the universe; we dwell among names and symbols. The animals remain in nature among things. We forget and remember intermittently that we are natural events; the animals do not comprehend the distinction. We are caught, seemingly forever, between being and nothingness; they, equally eternally, are. The paradox is that we are one of them and could not have come into being without billions of their prior generations. Our difference is still an animal thing. And, apparently, they could not have quarantined forever the symbol and the name.

Any animal brings a certain amount of sentience into the world, even a protozoan amoeba. Compared to a sponge or jellyfish the many species of worms are highly intelligent; compared to any of them the snails and insects are virtual philosophers. The octopus and salmon are beginning to individuate and have the inklings of personalities. Anphibians and reptiles have become partially individuated, so in myths and fairy tales we give them voices and let ther speak in their own behalf.

The thoughts of warm-blooded animals are literally in their bloodstreams. These creatures appear to dream in sleep as we do, to probe the world with a slightly detached curiosity snakes and frogs never have. 
Bears, seals, dogs, horses, mice, cats, and even birds are "people" by our standards-people in their own classes set off from regular human society. In a great number of cultures other mammals and birds have higher social standing than some human beings. Conversely, humans can be made into "animals," through caste system, slavery, and the taking of prisoners in warfare.

Monkeys and apes live at the boundary of our condition. After the fact they look like unfinished replicas of human beings, Like us they live in groups; they chatter; they play; they are curious (the rest of the mammals and birds are not as spontaneous in either behavior or speech).

There is the perhaps apocryphal story of the laboratory chimpanzee raised as just another child in a family among children. When funds for the experiment ran out, the chimpanzee was taken to a zoo. There he/she sat, behind bars, to him/herself a child, crying, and wondering why he/she had been put in a cage with apes. On the other side of the coin is the abandoned child raised by wolves who growls at humans and refuses to speak. These contemporary legends not only reify our guilt about the animals but expose our apprehension of their nearness to us.

We are far more alone than we usually realize. Because the animals resemble us we think that they aim at our designs and fall short. We project our motivations onto their actions, judging them only by their apparent functional goals. But ants do not build cities or fight wars; squids do not dance seductively to attract mates. They respond to their own bodies and ganglia, their ruffled flesh, the ancestral habits of their lineage. We can describe a dragonfly's activities but we cannot know the wingspread it feels as it beats its helicoid cuticles. We cannot imagine the intimacy of currents against a fish or a whale's big song. We have no inner reference for the taste of honey to a bee or the magnet that pulls the eel upstrearn.

Long prior to language a creature experiences itself and its own existence as real; it knows exactly who else is real. Alien beings may suggest "food" or "danger," but they are not "people." The spider looking at another spider sees the same thing we see when we look at each other--another human being (to universalize our term). If we were somehow reincarnated in their bodies we would find spiders as irresistible as we now find the partners of our own species.

Peacocks and pheasants display iridescent colors and parade before their prospective mates. Other species of birds hiss, raise their tails, and spread their wings. Fighting fish open their fins like painted parasols. The male dytiscus beetle strums a rhythmic tune on his femoral ring using his hind legs. Songbirds call each other with the same haunting melodies, again and again. The female spider casts down a thread and slides part way along it; the male catches the bottom and climbs up to meet her. She still may decide to eat instead of mate with him, but he strokes and feels her body with swift jittery legs and then plunges his palp deep into her vagina. He may even wrap her in a cocoon of his silk so she is immobile while he enters her.

Crab ancestors initiate what become Panamanian carnival dances. Moths are drawn to each other by smells which, to us, resemble raspberries and vanilla. In some species of flies the males compose a dancing swarm, and this stirs the otherwise placid females from among the bushes. It would seem that the women are transfixed by the pattern of the dance; they do not see the individual males but the swarm itself.

More than any other feature of the primordial animal world, sexuality looks like language. In their foreplay even snails and clams seem to recognize their psyches, to respond to the differentiation of the other within desire. Warm-blooded animals are dimly conscious of the festival. Sea swallows transfer fish from the beak of one to another during the dance of mating; orangutans embrace and nuzzle as they hang breast to breast by their arms from branches. Flying foxes hug similarly in the air, and beavers kiss while paddling through water.

Obviously, our body images, instincts, desires, and rituals come directly from our animal heritage (if not from any animals presently on the Earth). Still something stands between us; despite the development of the human psyche by mere degrees of cellstuff, there is an unpassable barrier between the existential situation of the human and that of any animal. It has been called language, symbol manipulation, experience of past and future, and, of course, the soul; 
but, whatever it is, it is important not because it is "human" (it can occur in quite alien creatures on other worlds) but because it changes the nature of the universe through the creature that embodies it.

Animal behavior is almost fully unconscious and compelled. No matter how complex the notes in the song or the steps in the dance, these creatures do them because they are them. Their sexuality brings them into contact with beings of their own kinds and provides the thread of continued life for the species. This is what the mysterious notes in the song mean to them, but to us, they remain nostalgic in another way. Their guttural resonance we find pastoral; they are a pure form of a thing we experience derivatively. They seem like abandoned comitment to natural desire, however contrived and ritually constrained the acts thernselves. (Of course, we may also become quite mimetic in our passions and so-called spontaneous tremblings; we are not the carefree dancers we pretend to be.) $s$

Finally we cannot interrupt the animals, either within or without, because we cannot address them. We can only enrage them, distract them, torture them, bore them, or trick them (and ourselves) into believing we are not there. They will keep their dignity forever. The experimental scientist towers over the bee in generations of intelligence but he/she is puny against the fixed time of its species.

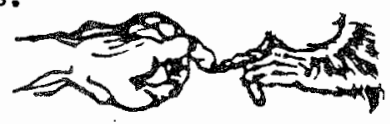

our animal/human dualism is a trap. The more we emphasize the differences and attempt to elevate ourselves to a superior realm, the more the similarities jolt us back into the animal kingdom. The new sciences of ethology, ecology, and sociobiology consistently discover that Homo sapiens is just another animal species and our inventive behavior originates in typical mamalian and chordate organs. On the other hand, when we minimize the differences and proclaim with egalitarian determination that we are just another animal, our very act of self-realization refutes itself: What other animal could redefine the criterial of its taxonomy?

The polar positions may reflect ideology more than zoology. Claiming our status is purely animal, we justify our wars, our social injustices, our sexual abuses, and our greed. "The territorial imperative." wrote Robert Ardrey, "is as blind as a cave fish, as consuring as a furnace, and it conmands beyond logic, opposes all reason, subsunes all moralities, strives for no goal more sublime than survival." Or, invoking the more primitive and brutal passages of the JudaeoChristian Bible, "human supremacists" argue (from the opposite position) that "man" was created to have dominion over the animals and thus may use their lives and bodies as "he" wishes. The conviction of this dominion (whether divine or biological) is so deeply ingrained in our species that men may apply it to women-inen who are otherwise politically liberal (or even radical) often tacitly promote the subjugation of women.

These pretexts of superiority are rather late and labyrinthine exercises in selfvindication. Animals are hardly pacifists or jurists, but they are rarely as arbitrarily ruthless as we. The tenderness of the crocodile mother with her babies stands against the rampant child abuse in our species, not in every instance of reptile and human but as a measure of their intrinsic capacity for humane behavior. We have the required neural structures for restraint and compassion, and our survival has depended on a shaky selfimposed peace even from our Palaeocene incipience. Yet we are more callous than many of the "dumb" beasts. ("Practice love first on animals, they are more sensitive," wrote Gurdjieff on the walls of the study House at the Prieure.)

The answer lies not in sterile flight from the wild. our self-conscious attempts to escape the animal kingdorn turn us into stiffened robots. The pompously "human" human being is not our model for higher consciousness; in fact such men and women seem to have lost the animal's supple inherence in the universe, its native wisdom. Their pretenses are only stereotypically intelligent.

"When man does not admit that he is an animal, he is less than an animal," wrote Michael McClure. "Not more but less."

Higher functions come not from transcending the animal kingdon but from experiencing the unity of animal existence in a new way. The seal scanning the blue underwater light was transforned into the child learning the names of flowers and the scientist focusing images of galaxies in mirrors. Through the biology of our becoming we have turned 
the pure pain (and pleasure) of the flesh into words and concepts winich explain and also alter our existence. Animal personalities have been incorporated into human personalities. Pigs and leopards remain inside us. Animal muteness has given rise to human speech.

The animals still do not face us with totally dumb and brute visages. Often they look like mirrors of us--our viciousness but also our tenderness and our flights of sonatic joy. The hunter focuses on this projection of his/her own sentience through the sight of the gun; unless he/she is engaged in sone clearly restorative ceremony, his/her choice to fire is also an attempt to blast $\mathrm{him} /$ herself out of the animal kingdom, though on another level he/she must change places with a creature by destroying the very aspect that is most sentient. It is his/her own sympathy he/she kills along with the deer or rabbit. The people shooting at wolves from helicopters, leaving their gasping bodies in the snow, are turning into something. They are becoming less alive, deed by deed.

We have the illusion of having created a safer universe, one that holds wild animals, like diseases, at bay. We now create our own horrors and these may be far worse than any suffered by animals, or by us as animals. The fear of loneliness and the ever-present spector of death replace the dismembering of the hare by the fox. The final terror has become the Word (so we experience pain in its absence, almost continuously, and die many times before our death), but the word is also an elixir, and we can be reborn or transformed.

The human experience can oppose and even reverse the animal through language. In culture the territorial imperative can lead also to treaties, migrations, and even pacifism. A wealthy Chinese landholder takes all his money and treasures out into the ocean in a sailing vessel and throws them overboard as an offering to the Dragon King who lives at the bottom. A warrior studies judo for twenty years in onder to learn how not to fight. Generations of meat eaters reflect on their heritage and adopt vegetarian diets. Monks sit naked in caves through long winters, trying to see past the dross of minds to a state of perfect mindlessness.

We inherit the brief flares of awareness that enable a crab to find food, to awaken to its hunger in the mass of organized chemicals it constellates, to extend its claw and move across the sand. We use symbols brought into being by the ancestors of both crabs and us, and from these create the alphabets and $\mathrm{Ci}$ ties the animals reflect. The brilliant yellow of the fish in the aquarium, the blue and violet plunage of the birds in the cage delight us because they are statements prior to language. Something reaches out of the darkness in these colorations, and that in us which reaches out of the darkness too, our mystery, meets it in admiration of the sullen beauty. The wonder of consciousness is that it seems to arise from nature and to have nothing to do with it, that it is grounded in raw hunger and predation, yet gives rise to compassion and justice. Cells eat before they do anything else, and that eating, transferred phylogenetically through psyche, becomes a vision of a peaceable kingdom in which the lion lies down with the lamb. What other system has encompassed a greater reversal?

Still, we should not forget Freud's warning; for us too: Anatory is destiny. The struggle we see in nature is real, and we cannot get away from it by taboos, laws, or science of behavior. The silence of the animals when we address thern is not simply their own constitutional intransigence; it is the silence of them still present in us.

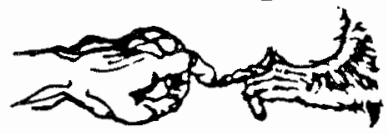

over vast generations global morphogenesis succeeds--the domant loci sinking beneath like Sleeping Beauty, to be awakened in a subsequent aeon by a kiss from a pagan knight.

We, as well as the other creatures on this world, contain vast documents of information about life, but most of it has been absorbed in the intracellular unconsciousness of our soma. The futurist and biologist John Todd told me recently of a discussion he had with another futurist, Lyall watson. They were talking about the way that we have been reinvading each other through viruses for millennia, so parts of plants and animals are continuously transferred back and forth between one another and stored in viral nucleic acids. Watson's theory, in Todd's words, is ". - That the silence in you represents the genetic imprint of all other beings. The silence in the oak is the genetic imprint of 
beings other than the cak. Even extinct creatures continue to exist. They're carried in some way in other creatures. Can you imagine! We could dance back that which is gone. What a project for civilization! we could bring back the pterodactyl or some ancient armored fish. Watson thought it might be easier to recreate a species that left recently. The animal he would elect to dance back is Stellar's sea cow which was last seen about 1886 off Alaska. It's not science-fiction stuff. It swings back directly on who we are and what our place is in the universe. Maybe it will make us more careful stewards. I haven't said much about love but I can't help but feel that's what this is all about."

Whether or not the biological universe exists hologrammatically in each of us, we can see that we are in the bare infancy of understanding the genetic code and who we are. If so much information lies buried within, life is a unity to a depth not believed possible since the mechanical universe replaced the Gnostic one. But we should not be overly optimistic, for much work lies ahead. If we are to recover our destiny, we must soften to what we are and allow ourselves to reach and reconcile those aspects of our nature (and nature itself) that we have destroyed in becoming, and have embodied silently. We also contain frightful malignancies, tumors and shapeless growths that destroy both form and memory. We have yet to discover whether we are the stewards or the destroyers, the radiant ovum of life or the malignant horde. There is no doubt we intuit the battle within, and it is not a simple matter of light and darkness, consciousness and unconsciousness, for sometimes the way to go is into darkness, where we begin.

We are gradually coming to accept a disturbing script. We are the collective imprint of trillions of individual creatures each of which has had its full manifestation suppressed. If we hear voices, some of then may be very ancient indeed and (in . fact) inseparable from what we are. It takes some effort to summon unity from our many origins, and it is not because we are made of parts. We are made of other unities. Splintered, we becone first dozens, then hundreds, then thousands of distinct creatures, who would no

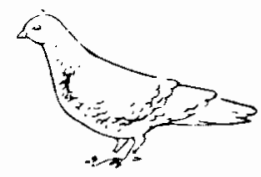

doubt stir to life if awakened, and would manifest as we do.

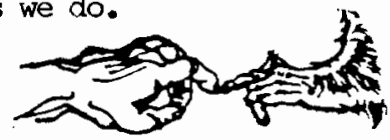

Although there is no clear point in the history of creatures when number and concentration of neurons cross the threshold and ignite mind, we presume that it is the great number of sense cells and their ramifications in grids and hierarchies that generate thoughts and awareness. What could never be explained qualitatively is now given a solely quantitative justification. The machine synthesis of intelligence is reapplied to nature; the more circuits, the more complete the "mind." The chimpanzee remains forever subhuman because it does not have enough circuits in his brain; the wolf has even fewer, the frog fewer than the wolf, and the worm is presumed not even to know it exists. The jellyfish and the sponge, for all intents and purposes, do not exist. This is the current official status of our troubled relationship with the animal kingdom.

Computers challenge our other flank. It has become difficult for us to say what distinguishes our seemingly natural intelligence from the artificial intelligence of electrode brains. How can we know if machines have minds without knowing what gives our minds? The existential crisis in our political and economic institutions mirrors and is mirrored by the crisis of our identity. The number and relationship of neurons becomes not just the threshold of mind, it becomes a statement of being and not-being. It is because it is such a precarious statement of such a crucial matter that we cling rather desperately to the remaining shards of humanity. If we are a mere quantitative degree removed from bestiality, then we are not removed from it at all. The more conscious we become, the more we perceive the imminent deterioration of consciousness.

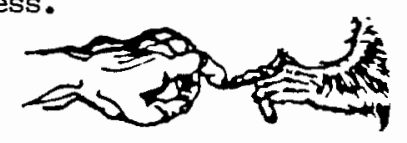

At the moment life begins, mind begins too. Even in the primitive sponges where cells are barely associated, matter begins to astonish itself by its own existence. "How?" it asks. "How am I here?" We can see the question forming in crabs and snails, in the eyes of sullen fishes. Predators may prowl, kill, and feed unconsciously, but there is a hint of consciousness, a doubt, a brief dissociation between the self and the act. "It 
is ludicrous that I should be this thing." all things think. The bear whines restlessly, the lynx looks curiously to the clouds and blue sky-whatever it calls them to itself; even the walnus wonders why it has to cart this immense blubber across the rocks. Each of the animals is a combination of something anu nothing, a question that refuses to ask itself, an obliteration that floats on the margins of waves of air before crumbling in a heap of feathers and protoplasm. The frog sits on the shores and chants. Lion and zebra face and become each other at the kill. Cats and dogs occasionally look to us for the answer because we act as though we know what is happening. Monkeys in the Amazonian foliage look down at the Indians painting themselves for the ceremony, not aware that they are equally not aware.

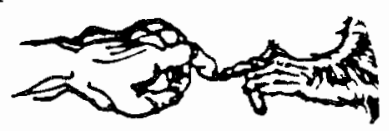

Remember the cry of history as a nightmare from which we cannot awake. For fifty million years primates existed in the forests of New World and old without the hint of humans. Millennia earlier dolphins and whales returned to the sea, and more generations of them have lived and died there from the whole of mankind back to the aboriginal tribes of Africa.

The disjumction between society and nature is never complete. This far into history, nature has been unable to reestablish pure unconsciousness, unbroken jungles and algae seas. Nor have we been able to extinguish, by cities and machines and industrial fires, the dormancy that constitutes most of this planet still. Unless we fail, both of us have a long way to go, hand in hand, approaching the light as we approach the final darkness.

This far along in the process, it hardly helps to try to becone less human. For one, the passage back (as everywhere) is through psyche, which will deflect it. our "animal" methods are always semantic, and thus, artificial. For two, animal existence is unconscious; so the less human one beoomes, the more one loses the "ego" of the desire. If one achieved total dehumanization, which is impossible, the libido might be liberated, but it would no longer be human. As dear as the ideal of the pure orgy is to the human heart it seems to lead inevitably to degradation and mutilation, even among previously humane lovers.
Wilhelm Reich took a different point of view on sublimation. He asserted that libido was far stronger and more fundamental to our nature, even in its raw state. Sexual desire connects us to the vital fluid of life itself, and , in our contact with libidinal energy, further life is given expression and form. According to Reich, and in absolute contradiction to Freud, men and wonen could have the whole of sexuality and still be human. Desire transcends language; desire can give the gift without a symbol; desire is the gift.' Taboos and sexual perversions are thus diseases we have imposed on ourselves ollectively over time through our submission to civilization.

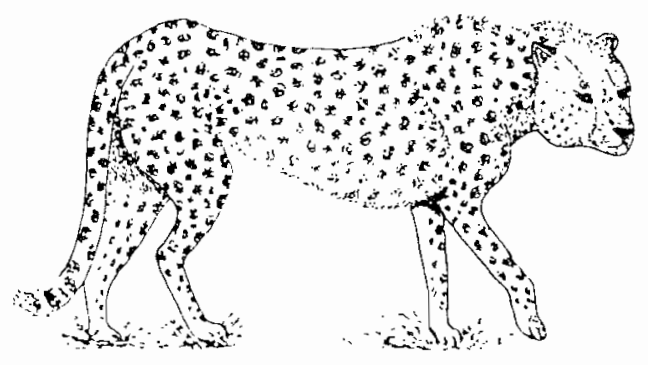

Reich adopts a moral position in place of a psychological one, but it is unclear where his enemy cane from. Culture apparently arose from nature without any extrinsic intercession. And nature, prior to man and woman, is filled with acts of sadomasochism that outdo even the most decadent human practices. If sexuality were born as love in the world of nature and then corrupted by men and women (or men alone in the feminist argument), then nature would have two remedies: either it could provide us with a means of curing ourselves (since the disease is not natal); or it could kill us off and try the experiment of consciousness again with a more humane species. However, it is possible that love does not precede us, that we are still bringing love into existence through eros, though language, that crocodiles, ravens, and whales (to mention just a few of the others) are equally in the process of bringing love into the world through their own glimers of consciousness, and that this process has been going on since the origin of life.

But we are also shadowed by the unnamed hungers of beasts not in our lineage. The fernale spider devours her mate, the mantis dismembers and eats her lover during the act 
of intercourse. Are these bodily expressions of an actual psyche, or are they only the chenical activities of cells? Are we trapped in the libido of the spider, or do we merely pretend to be in order to evade the subtle prana of love? Twentieth-century pornographers have lost the distinction between pleasure and pain. Despite a wealth of artificial erotica, their passions draw no image, so they invoke gang rape and dismernberment to take thenselves to the bottom, beyond which, they hope, there is no mystery, no allure. The animals become their projections of unexperienced lusts, but they have no idea who the animals actually are.

We cannot be carnivores without being killens too. From the point of view of plants, we are just another mutant that has lost the ability to feed directly from the Sun. What if this ability were regained and transmitted through the cells? This would be remarkable, considering the thousands of years of predation our metabolism enbodies. our apologia for the whole aninal kingdom is based on the circumstantial evidence that there is no other path to knowledge. Yogis still promise we can someday materialize the right chords to draw our sustenance from vibrations of air, without killing even plant life, to draw from the sun and the psychic field around us, but if that's where we're headed, obviously have a long way to go.

No diagnosis of the problem or possible solution is no longer too extreme. We miss the point when we act only conscientiously, so even our humanitarian gestures are confounded. This media-conscious, high-technology civilization creates the mirage of progress against famine, tyranny, and disease. But, in self-protection, we are blind. Between the unnamed forces of yoodoo and the quantum dance of atoms lie untold universes of suffering and redemption. We may pretend to heal the Earth, but what about whole civilizations destroyed on other planets, individuals in pain on worlds around other suns? If we were to accomplish a lasting peace on our world, would we then have to worry about other planets that perhaps do not even exist? But if they do, they are part of the universe, part of consciousness; and, ultimately our sympathy must be extended through eternity to those victims too, creatures we could never know. Not because it does any good but because it forces us to view the crisis in its actual bigness while at the same time reminding us that we do not know who and where we are and thus what powers we have. If we could bring peace to this planet, we could probably bring peace to the universe.

We do not know. But that is not the problem. The problem is that we pretend to know, or think we should pretend. We think we know what we are and what the world should be. But nothing about cell life, or $\mathrm{DNA}$, or the self-assembly of tissue suggests we have any idea of whence we cane into being. our whole culture and technology might be an invasion of our natural condition, our true dormant power. We could be avoiding our own natures, missing the solutions to our crises; worlds without end moce fulfilling than this one might be within our grasp. But these lie in the margins of an unconscious inner life we presently flee in all our ideologies and institutions. It would seen now to have to begin in silence again. We must drop all our expectations and see just how quiet and observant we can be-keeping our eye perfectly on each thing as it arises. We have created so mach noise; yet the thing we are is so soundless and perfect it might simply become.

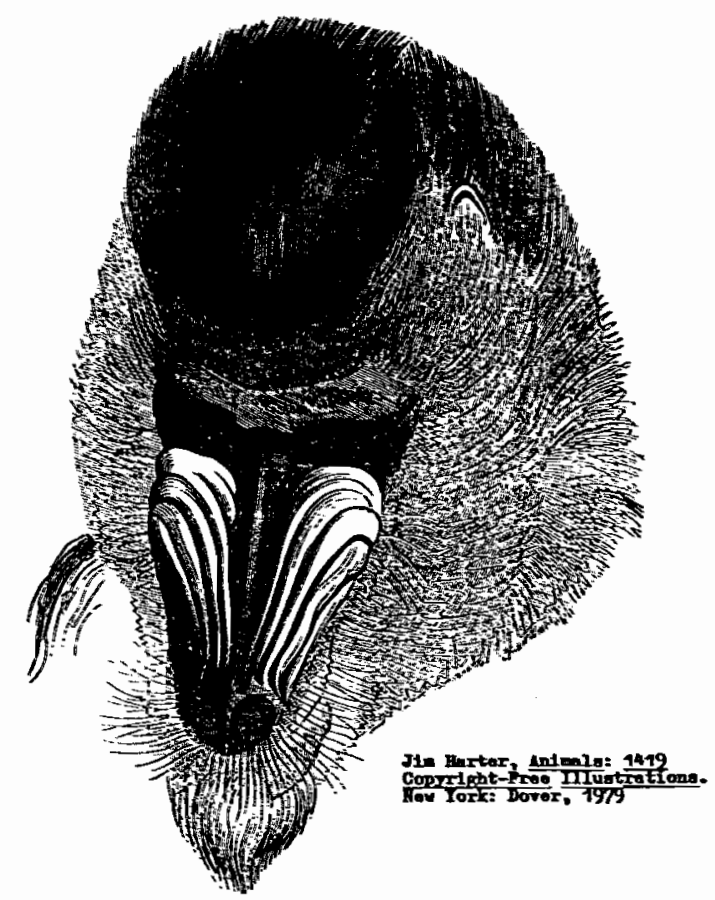

These selections from EMRRYOGENESIS are arranged in different order from that in which they appear in the original text. Richard Grossinger. edits the journal $I O$ and is the author of many works, including Planet Medicine (Anchor, 1980) and The Night Sky (Sierra Club Books, 1981). 